\title{
Ocena dynamiki spalania propelantów w środowisku węgla kamiennego
}

\begin{abstract}
Artykuł opracowano na podstawie wyników badań zrealizowanego projektu szczelinowania gazowego próbek węgla kamiennego z wykorzystaniem materiałów wysokoenergetycznych - propelantów, w skali laboratoryjnej. Założeniem projektu było sprawdzenie, czy metoda stymulacji przepływu mediów ze złoża do odwiertu, znana z zastosowań w przemyśle naftowym przy konwencjonalnych złożach węglowodorów, może zostać wykorzystana w przypadku złóż metanu z pokładów węgla kamiennego (CBM). Metoda szczelinowania gazowego z zastosowaniem materiałów wysokoenergetycznych opiera się na niedetonacyjnym wykonaniu kilku radialnych szczelin w strefie przyotworowej, poprzez oddziaływanie ciśnienia gazów prochowych, powstałych w wyniku inicjacji propelantów. Zakres pracy obejmował serię testów szczelinowania gazowego w warunkach poligonowych na próbkach węgla kamiennego, które zostały zeskanowane tomografem komputerowym, przed i po próbach ciśnieniowych z wykorzystaniem materiałów wysokoenergetycznych. Zabieg szczelinowania wykonano w laboratoryjnym silniku rakietowym (LSR), odpowiednio dostosowanym do badań na próbkach węgli. Uzyskane obrazy spękań poddano analizie porównawczej z obrazami pierwotnej sieci spękań w węglach oraz opisano występujące pomiędzy nimi różnice. Dodatkowo przeanalizowano wykresy ciśnienia w komorze silnika laboratoryjnego, powstałe w trakcie badań.
\end{abstract}

Słowa kluczowe: CBM, stymulacja otworu, szczelinowanie gazowe, propelanty, tomografia komputerowa.

\section{Evaluation of propellant combustion dynamics in coal environment}

The article is based on the results of a research project concerning gas fracturing of coal samples using high-energetic materials - propellants, in a laboratory scale. The project assumption was to verify that the method of stimulating the flow of media from a reservoir to a well, already known from use in the petroleum industry on conventional hydrocarbon reservoirs, could be applicable to coal bed methane (CBM). The gas fracturing method using high-energy materials is based on the non-explosive execution of several radial fractures in the near-well area, by the pressure from combustion gas produced by propellant initiation. The scope of work, included a series of gas fracturing tests in fireground conditions, on coal samples that had been scanned by computer tomography before and after pressure testing, with high energy materials. The fracturing process was done in a laboratory rocket engine (LSR), suitably adapted to the test on carbon samples. The fractures' images obtained were subjected to comparative analysis with the images of the native fracture system in coals and differences between them adequately described. In addition, the charts of pressure generated during the tests in the laboratory engine compartment were analyzed.

Key words: CBM, well stimulation, gas fracturing, propellants, computed tomography.

\section{Wstęp}

Za rentownością wydobycia metanu z pokładów węgla kamiennego przemawiają trzy główne argumenty:
- skuteczne odmetanowanie kopalń węgla kamiennego poprawi bezpieczeństwo pracujących pod ziemią górników, 
- podczas wentylacji kopalni znaczna część metanu wypuszczana jest do atmosfery, wychwytywanie go przyczyniłoby się do poprawy kondycji środowiska naturalnego,

- pozyskanie metanu w znacznych ilościach poprawiłoby bezpieczeństwo energetyczne kraju.

Zgodnie z bilansem złóż kopalin przygotowanym przez Państwowy Instytut Geologiczny w 2014 roku zasoby bilansowe metanu pokładów węgla w GZW dla 58 udokumentowanych złóż wynosiły $86,8 \mathrm{mld} \mathrm{m}^{3}$, z czego zasoby przemysłowe dla 26 złóż stanowiły $5,611 \mathrm{mld} \mathrm{m}^{3}[6]$.

CBM zalicza się do niekonwencjonalnych złóż węglowodorów, które wcześniej nie były ekonomicznie eksploatowane, ze względu na brak odpowiedniej technologii ich wydobycia [5]. Węgiel kamienny w swej fizycznej postaci składa się z trzech głównych składników: matrycy skalnej (organicznej), przestrzeni wolnej w postaci porów i szczelin oraz części mineralnej (nieorganicznej). O ile składniki organiczne determinują zdolność sorpcyjną i stopień dyfuzji metanu, to sieci porów i szczelin w głównej mierze stanowią o przepuszczalności i produktywności pokładu, będąc ważną drogą przepływu gazu w złożu [7].

Metan w pokładach węgla utrzymywany jest w równowadze poprzez ciśnienie otaczających go wód złożowych zgromadzonych w naturalnym systemie spękań. W celu uwolnienia przepływu metanu z węgla kamiennego wykonuje się zabiegi obniżenia ciśnienia w złożu poprzez odprężenie górotworu, powodowane odwodnieniem pokładów węgla [4]. Po obniżeniu ciśnienia w górotworze do wartości izotermy sorpcji następuje proces uwolnienia metanu z pokładów węgla (proces desorpcji), który trwa do osiągnięcia ciśnienia końcowego ze względu na to, że węgiel ma bardzo niską przepuszczalność. Przypływ metanu w wyniku obniżenia ciśnienia $\mathrm{z}$ zastosowaniem odwodnienia pokładów jest niewielki. Dlatego w celu intensyfikacji wydobycia stosuje się specjalne metody eksploatacji.

Jedną ze skutecznych metod stymulacji może okazać się szczelinowanie gazowe z wykorzystaniem propelantów, niestosowane dotąd do stymulacji pokładów węgla kamiennego $[2,3]$. Szczelinowanie gazowe materiałami wysokoenergetycznymi polega na niedetonacyjnym wykonaniu kilku radialnych spękań w strefie przyodwiertowej. Spękania powstają w wyniku wygenerowania przez spalające się propelanty ciśnienia gazów prochowych o wartościach przekraczających maksymalne naprężenie w górotworze [1].

\section{Metoda badawcza}

Celem prac poligonowych było sprawdzenie, czy metoda szczelinowania gazowego z wykorzystaniem materiałów wysokoenergetycznych może być skuteczna w zastosowaniu do próbek węgla kamiennego.

Metoda wykorzystana do badań opierała się na wyselekcjonowaniu dwóch próbek węgla kamiennego w kształcie walca i poddaniu ich skanowaniu tomografem komputerowym (CT) w celu określenia pierwotnej sieci spękań, przy wykorzystaniu specjalistycznych programów komputerowych: ImageJ, Avizo oraz Mavi. Stosując oprogramowanie komputerowe, uzyskano obraz graficzny i liczbowy sieci spękań występujących w próbkach węgla kamiennego.

Próbki węgla kamiennego wklejono za pomocą żywicy epoksydowej w specjalne oprawy umożliwiające szczelinowanie gazowe węgli. Zabiegi szczelinowania wykonano w laboratoryjnym silniku rakietowym, który został zmodyfikowany do badań na węglach (rysunek 1 , fotografia 1 ).

Do badań poligonowych wykorzystano małogabarytowe paliwo heterogeniczne (MPH), które zostało zainhibitowane folią poliestrową termokurczliwą, w celu obniżenia jego prędkości spalania.

Podczas badań poligonowych informacje na temat dynamiki spalania propelantu uzyskano przy użyciu piezoelektrycznego przetwornika ciśnienia o zakresie pomiarowym do $100 \mathrm{MPa}$, umieszczonego w komorze spalania paliwa w LSR.
Przy pomocy rejestratora ciśnienia odtworzono profil narastania ciśnienia w układzie.

Po próbach na poligonie badawczym całkowicie zeszlifowano obejmy, w których osadzone były walce węglowe, aby zapobiec pochłanianiu promieniowania gamma przez metal. Próbki węgla kolejno poddano ponownemu skanowaniu tomografem komputerowym, aby określić rezultaty szczelinowania gazowego.

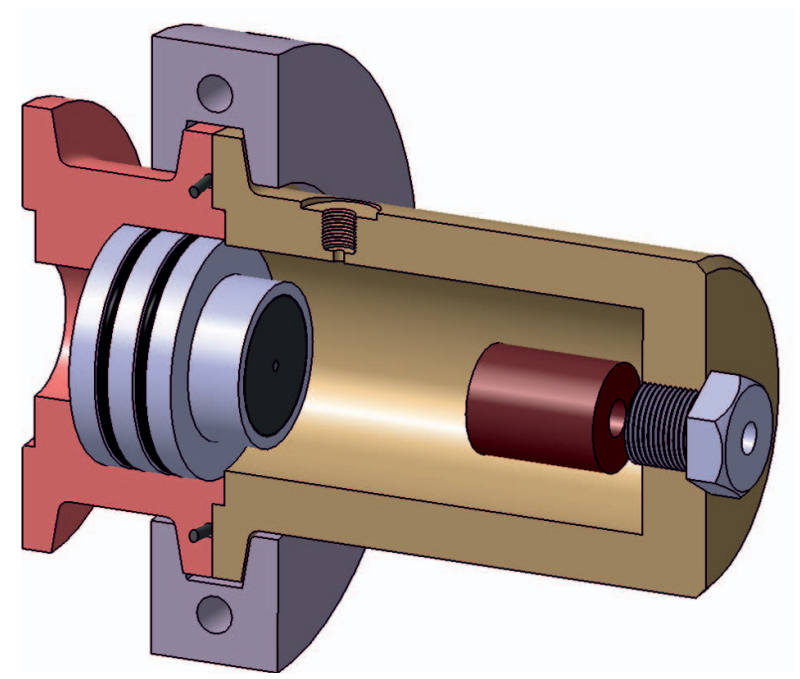

Rys. 1. Projekt silnika laboratoryjnego z dyszą węglową oraz paliwem w przekroju 


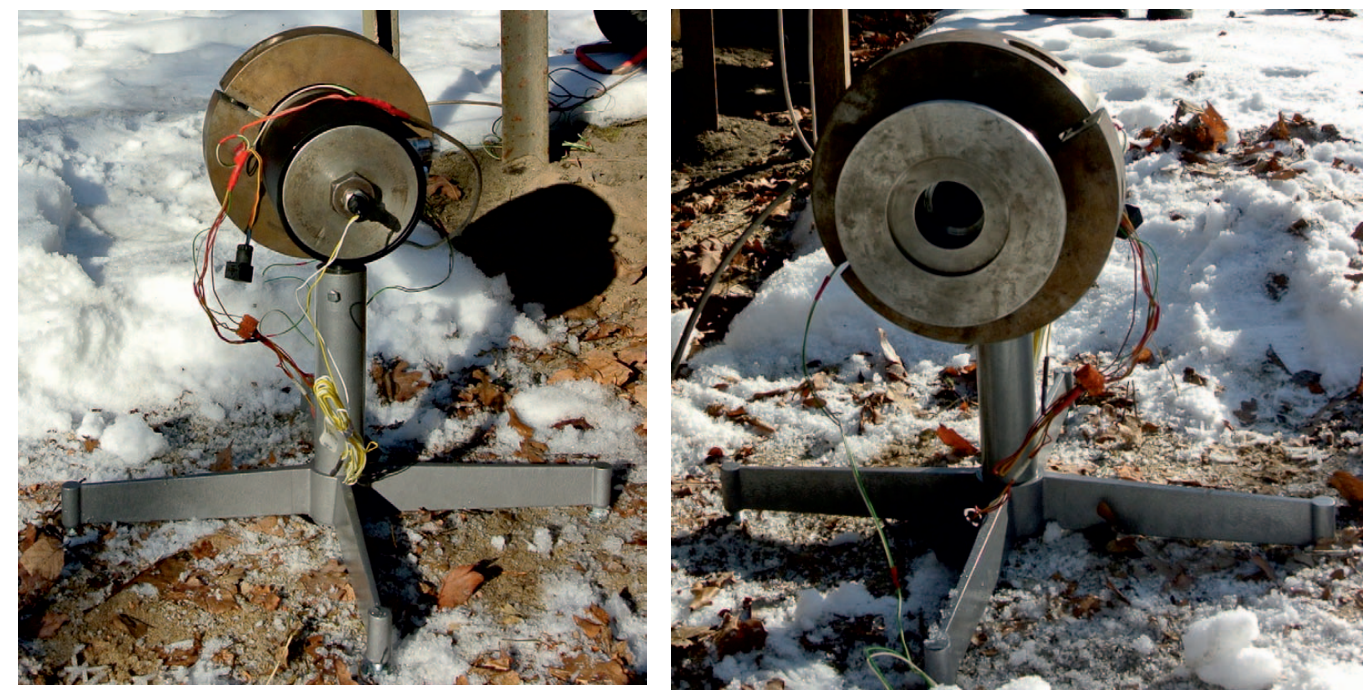

Fot. 1. Laboratoryjny silnik rakietowy przystosowany do badań na węglach

\section{Wyniki badań}

\section{Próbka numer 1}

Opracowanie danych rozpoczęto od cyfrowego zawężenia analizowanej przestrzeni do postaci sześcianu. Taka geometria próbki ułatwia interpretację i umożliwia skuteczne określenie sieci spękań występujących w badanym obszarze. Próbka węgla kamiennego charakteryzowała się następującymi parametrami: wysokość $h_{1}^{p}=13,7 \mathrm{~mm}$, boki o wymiarach $a_{1}^{p}=33,7 \mathrm{~mm}$, $b_{1}^{p}=39,9 \mathrm{~mm}$ oraz objętość próbki $v p_{1}^{p}=18421,4 \mathrm{~mm}^{3}$. Objętość spękań w próbce wynosiła $v s_{1}^{p}=260,64 \mathrm{~mm}^{3}$, co stanowiło 1,4\% objętości całej próbki.

Do próbki nr 1 wykorzystano ładunek propelantowy o masie $m_{1}^{p}=30 \mathrm{~g}$ oraz obliczono gęstość ładowania paliwa $\rho_{1}^{\text {tad. }}=0,05 \mathrm{~g} / \mathrm{cm}^{3}$. Po inicjacji paliwa układ badawczy szybko osiągnął ciśnienie maksymalne - 28,125 MPa po czasie 0,9 s. Ciśnienie w dużym stopniu uwolniło się z układu przez nieszczelność, co obniżyło wartość ciśnienia szczelinującego próbkę. Makroskopowo po próbie nr 1 widoczne jest nadpalenie próbki spowodowane działaniem gazów prochowych, a po przeciwnej stronie próbki obserwowane są wyraźne szczeliny (fotografia 2). Na wykresie ciśnienia w funkcji czasu układ badawczy bardzo szybko osiągnął wartość maksymalną ciśnienia, po czym powoli ono spadało, wydostając się z układu. Wykres ciśnienia sugeruje, że próbka węgla mogła zostać zeszczelinowana (rysunek 2).

Po zakończeniu prób ciśnieniowych próbkę poddano ponownemu skanowaniu CT. Z wykorzystaniem oprogramowania komputerowego próbkę węgla powtórnie ,przycięto” do postaci sześcianu o wymiarach $h_{1}^{p '}=13,55 \mathrm{~mm}$, z bokami o wymiarach $a_{1}^{p '}=39,4 \mathrm{~mm}$, $b_{1}^{p '}=45,1 \mathrm{~mm}$ oraz objętości $v p_{1}^{p}{ }^{\prime}=24077,5 \mathrm{~mm}^{3}$.
W próbce pojawiła się strefa spękań o znacznej objętości, jednak zdecydowano się zobrazować szczeliny o największej powierzchni. Zobrazowanie wszystkich szczelin sprawiłoby, że obraz byłby nieczytelny. Na rysunku 3 zestawiono ze sobą obrazy sieci spękań przed oraz po próbach ciśnieniowych z wykorzystaniem propelantów.
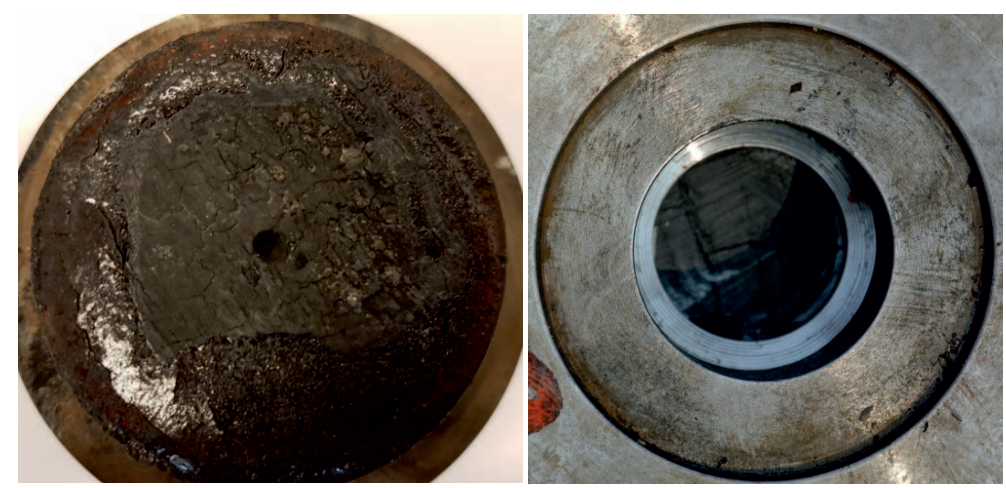

Fot. 2. Dysza węglowa po próbie szczelinowania nr 1

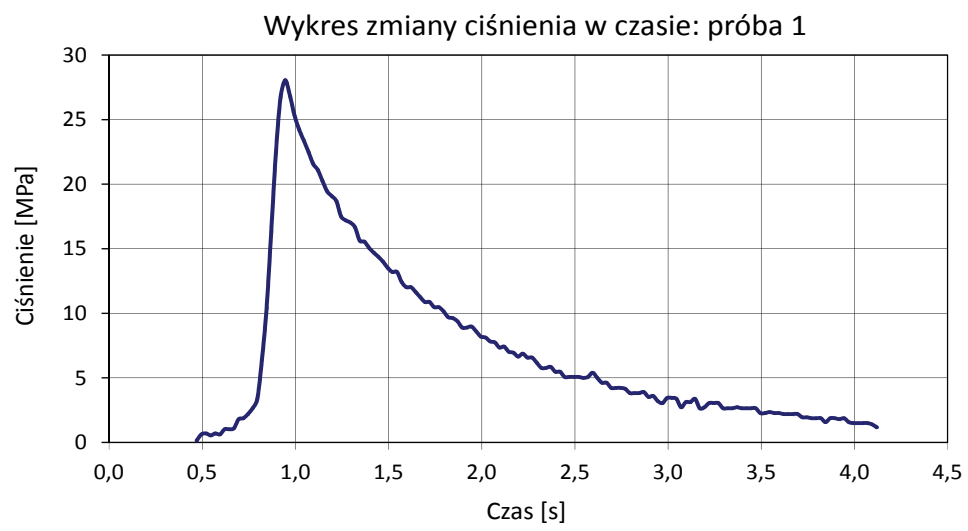

Rys. 2. Wykres ciśnienia dla próby nr 1 

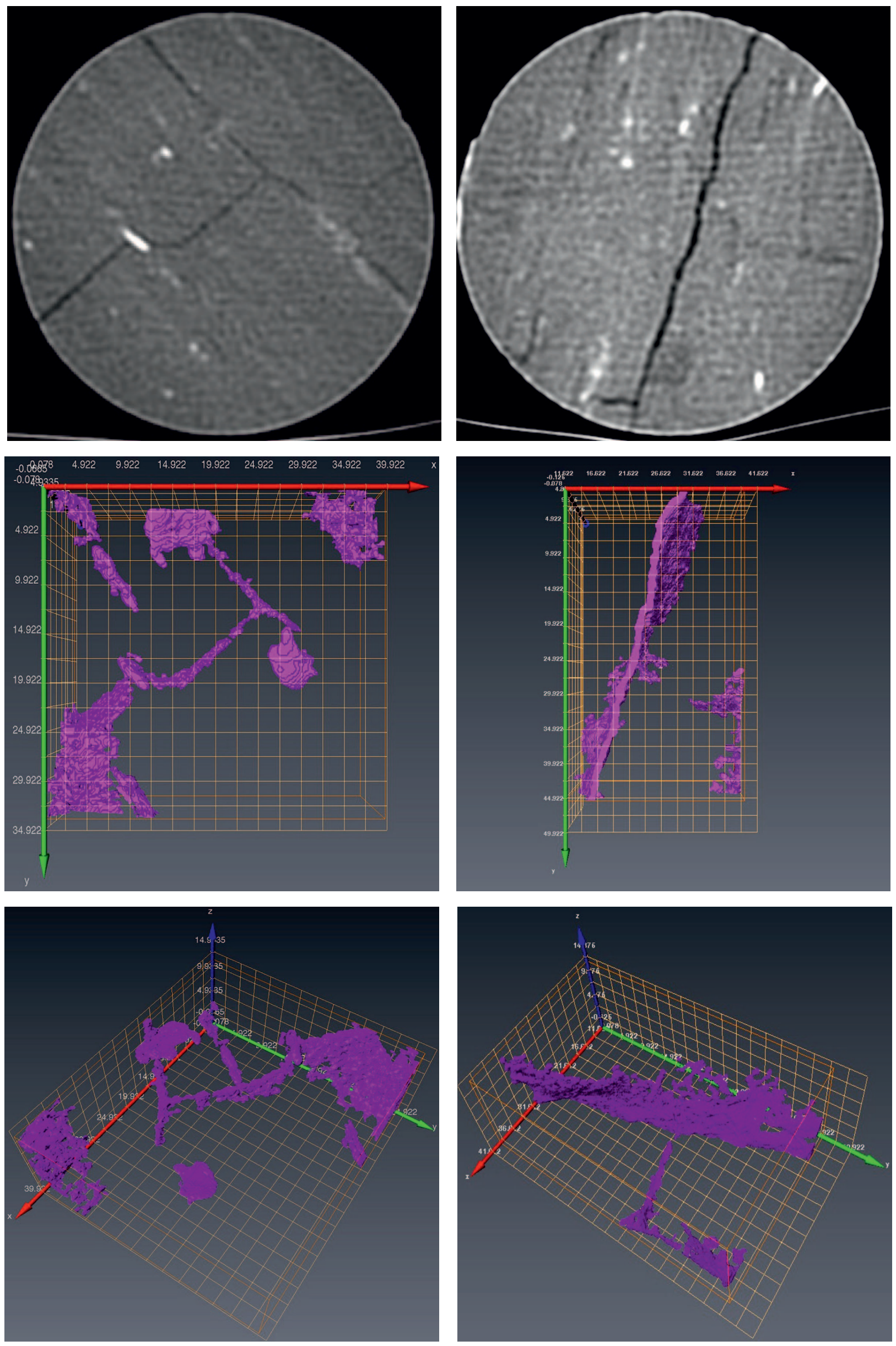

Rys. 3. Sieć spękań w próbce nr 1 przed i po szczelinowaniu gazowym 
Powstałe szczeliny w wyniku szczelinowania materiałami wysokoenergetycznymi mają objętość $1780,1 \mathrm{~mm}^{3}$, co stanowi 7,4\% całej próbki. Po zabiegu szczelinowania gazowego próbki nr 1 uzyskano „modelowe” szczeliny skrzydłowe. Są one najbardziej pożądane przy zabiegach szczelinowania gazowego, ze względu na ich zasięg.

\section{Próbka numer 2}

W drugim teście wykorzystano próbkę węgla kamiennego charakteryzującą się następującymi parametrami po ,przycięciu": wysokość $h_{2}^{p}=9,9 \mathrm{~mm}$, boki o wymiarach $a_{2}^{p}=34,9 \mathrm{~mm}$, $b_{2}^{p}=39,9 \mathrm{~mm}$ oraz objętości $v_{2}^{p}=13785,85 \mathrm{~mm}^{3}$. Następnie próbkę węgla poddano skanowaniu tomografem komputerowym. Uzyskano następujące wyniki: objętość spękań wynosiła $v s_{2}^{p}=1325,24 \mathrm{~mm}^{3}$, co stanowiło $9,6 \%$ objętości całej próbki.

Podczas próby $\mathrm{nr} 2$ wykorzystano $m_{2}^{p}=30,5 \mathrm{~g}$ paliwa MPH, gęstość ładowania wynosiła $\rho_{2}^{\text {tad. }}=0,05 \mathrm{~g} / \mathrm{cm}^{3}$. Po czasie 0,75 sekundy od inicjacji paliwa układ osiągnął ciśnienie maksymalne, które wyniosło 25,7 MPa. Makroskopowo próbka jest nadpalona w wyniku działania gazów prochowych. Po przeciwnej jej stronie widoczne są szczeliny oraz pustki powstałe $\mathrm{w}$ wyniku szczelinowania gazowego (fotografia 3 ). Otrzymany wykres ciśnienia wskazuje, że w układzie nastąpiło poprawne spalanie paliwa, mogące skutkować szczelinowaniem próbki (rysunek 4).

Podobnie jak w przypadku poprzedniego testu po zakończeniu prób ciśnieniowych próbkę odpowiednio przygotowano oraz poddano skanowaniu tomografem komputerowym. Po zakończeniu prób ciśnieniowych próbkę poddano ponownemu skanowaniu CT. Z wykorzystaniem oprogramowania komputerowego próbkę węgla kolejny raz „przycięto” do postaci sześcianu o wymiarach $h_{2}^{p}$ ' $=9,9 \mathrm{~mm}$, z bokami o wymiarach $a_{2}^{p}$ ' i $b_{2}^{p}$ ' $=39,9 \mathrm{~mm}$ oraz objętości $v p_{1}^{p \prime}=15760,9 \mathrm{~mm}^{3}$.
W próbce pojawiła się strefa o dużej przepuszczalności, dlatego zobrazowano wyłącznie szczeliny o największej powierzchni, aby obraz graficzny próbki był czytelny. Na rysunku 5 zestawiono ze sobą obrazy sieci spękań przed oraz po próbach ciśnieniowych z wykorzystaniem propelantów.

W próbce po szczelinowaniu paliwem MPH pojawiła się duża strefa przepuszczalności o objętości $v p_{1}^{p}=2164,48 \mathrm{~mm}^{3}$. Spękania stanowiły 14\% objętości całkowitej analizowanej próbki. Sieć spękań w próbce nr 2 powstała w wyniku przekroczenia maksymalnych naprężeń w układzie badawczym. Utworzona sieć spękań jest charakterystyczna dla torpedowania materiałami wybuchowymi, powstaje wtedy „klatka spękań” o niewielkim zasięgu.
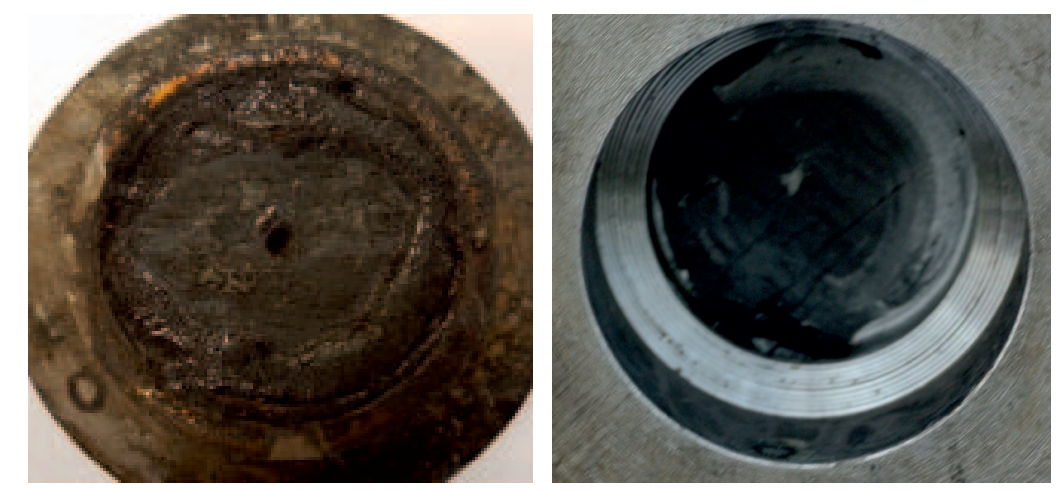

Fot. 3. Dysza węglowa po próbie szczelinowania nr 2

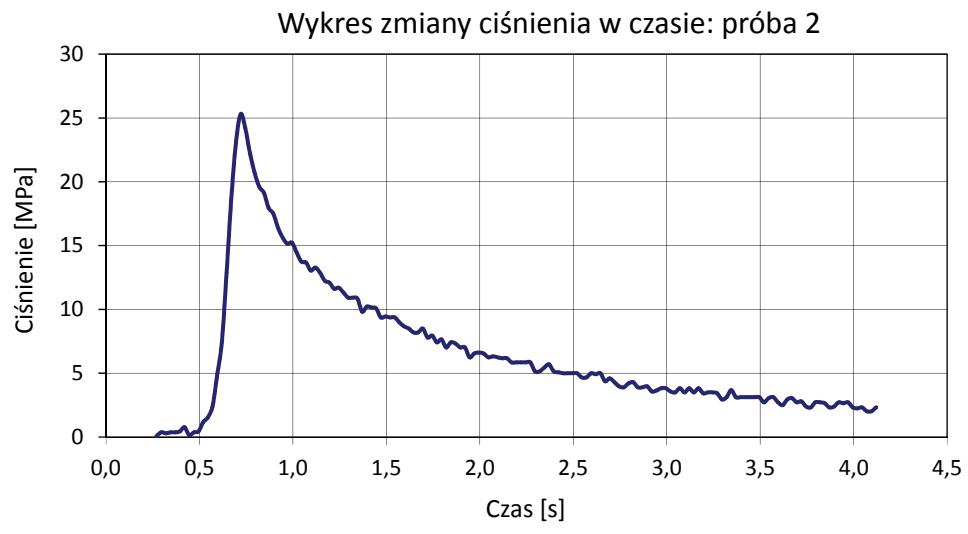

Rys. 4. Wykres ciśnienia dla próby nr 2

\section{Podsumowanie i wnioski}

1. Wyselekcjonowano próbki węgla kamiennego w celu wykonania na nich zabiegu szczelinowania gazowego z wykorzystaniem materiałów wysokoenergetycznych i określenia jego skuteczności.

2. Próbki węgla poddano skanowaniu tomografem komputerowym, analizie za pomocą specjalistycznego oprogramowania komputerowego: ImageJ, Avizo i Mavi, a także określono graficznie i liczbowo ich pierwotną sieć spękań.

3. Zaproponowano i przygotowano układ badawczy, w którym próbki węgla kamiennego wklejone w specjalne oprawy z wywierconym karbem, imitującym zalążek kanału perforacyjnego, mogły zostać poddane szczelinowaniu gazowemu w skali laboratoryjnej.

4. Przygotowano ładunki propelantowe MPH, inhibitowane folią poliestrową termokurczliwą o odpowiedniej masie, mogące wytworzyć odpowiednią ilość gazów pod wysokim ciśnieniem, aby zeszczelinować próbki węgla kamiennego.

5. Przeprowadzono serię prób szczelinowania gazowego próbek 

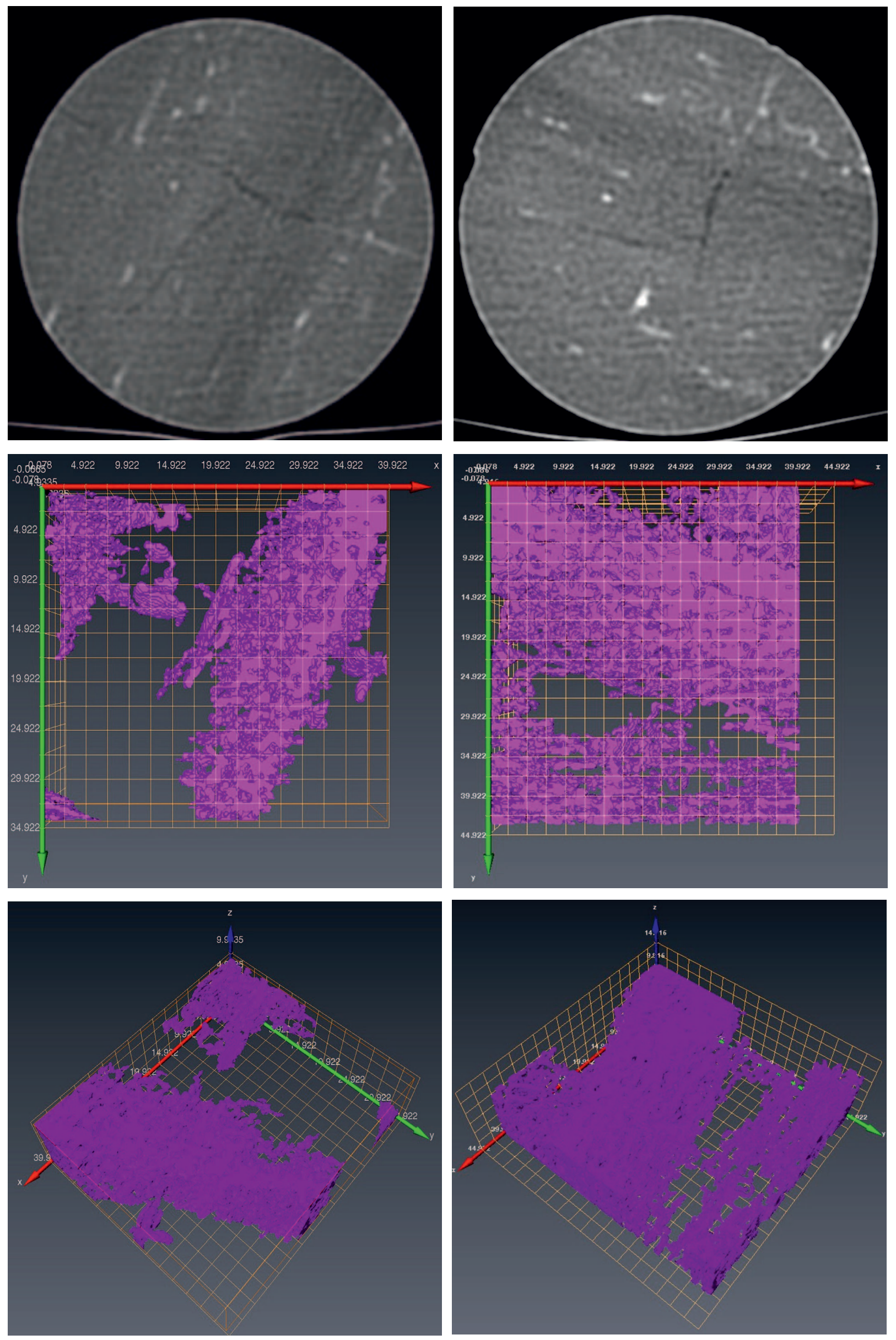

Rys. 5. Sieć spękań w próbce nr 2 przed i po szczelinowaniu gazowym 
węgla kamiennego materiałami wysokoenergetycznymi. Badanie zrealizowano w laboratoryjnym silniku rakietowym z rejestracją ciśnienia.

6. Wykonano ponowne skanowanie próbek CT, które przetworzono w programach komputerowych w celu określenia efektów szczelinowania graficznie i liczbowo.

7. Na podstawie rezultatów badań można wnioskować, że metoda stymulacji przepływu mediów ze złoża do otworu z wykorzystaniem materiałów wysokoenergetycznych może znaleźć zastosowanie przy szczelinowaniu węgla kamiennego. Wyniki badań jednoznacznie wskazują, że w analizowanych próbkach węgla kamiennego nastąpił przyrost szczelin po wykonaniu prób ciśnieniowych. W próbce nr 2 powstał rozległy układ spękań spowodowany zbyt wysokim ciśnieniem szczelinowania, jednak nie na tyle wysokim, aby całkowicie zniszczyć próbkę węgla. W przypadku próby nr 1 ciśnienie wytworzyło „modelową” szczelinę o znacznej powierzchni.

Prosimy cytować jako: Nafta-Gaz 2018, nr 1, s. 22-28, DOI: 10.18668/NG.2018.01.02

Artykuł nadesłano do Redakcji 13.07.2017 r. Zatwierdzono do druku 6.09.2017 r.

Artykuł powstał na podstawie pracy własnej pt.: Szczelinowanie gazowe z wykorzystaniem propelantów jako metoda stymulacji gazonośnych pokładów węla kamiennego - praca INiG - PIB; nr zlecenia: 1883/ST/01, nr archiwalny: DK-4100-205/16.

\section{Literatura}

[1] Frodyma A., Habera Ł.: Zasady oddziatywań fizycznych paliw stałych w środowisku otworu wiertniczego i skał złożonych $i$ ich implikacje dla prac stymulacyjnych. Materiały Wysokoenergetyczne 2013, t. 5, s. 59-71.

[2] Habera Ł.: Badania zapłonu propelantów na stacjonarnym silniku laboratoryjnym. Nafta-Gaz 2014, nr 11, s. 778-783.

[3] Habera Ł.: Szczelinowanie gazowe gazonośnych pokładów węgla kamiennego - badania poligonowe. Nafta-Gaz 2016, nr 12, s. 1063-1068, DOI: 10.18668/NG.2016.12.08.

[4] Hadro J., Wójcik I.: Metan pokładów węgla - zasoby i eksploatacja. Przegląd Geologiczny 2013, vol. 61, s. 404-410.

[5] Poprawa P.: System weglowodorowy z gazem ziemnym w tupkach - pótnocnoamerykańskie doświadczenia i europejskie perspektywy. Przegląd Geologiczny 2010, vol. 58, s. 216-225.

[6] Praca zbiorowa pod redakcją M. Szuflickiego, A. Malon, M. Tymińskiego: Bilans zasobów złóż kopalin w Polsce wg stanu na

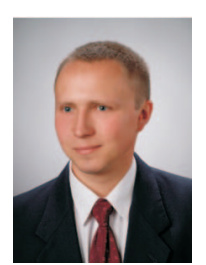

Dr inż. Łukasz HABERA

Adiunkt w Zakładzie Techniki Strzelniczej.

Instytut Nafty i Gazu - Państwowy Instytut Badawczy

ul. Lubicz $25 \mathrm{~A}$

31-503 Kraków

E-mail: lukasz.habera@inig.pl

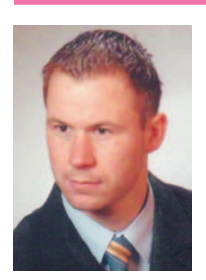

Mgr inż. Piotr KOŚLIK

Specjalista badawczo-techniczny w Instytucie

Przemysłu Organicznego w Warszawie Oddział

w Krupskim Młynie.

ul. Zawadzkiego 1

42-693 Krupski Młyn

E-mail:piotr.koslik@ipo.waw.pl
31 XII 2012. Państwowy Instytut Geologiczny - Państwowy Instytut Badawczy, Warszawa 2015, s. 26-29.

[7] Yanbin Yao, Dameng Liu, Yao Che, Dazhen Tang, Shuheng Tang, Wenhui Huang: Non-destructive characterization of coal samples from China using microfocus $X$-ray computed tomography. International Journal of Coal Geology 2009.

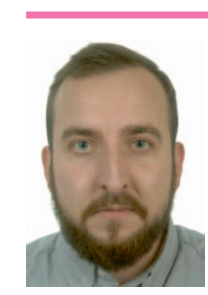

Mgr inż. Kamil Hebda

Specjalista inżynieryjno-techniczny w Zakładzie

Techniki Strzelniczej

Instytut Nafty i Gazu - Państwowy Instytut Badawczy ul. Lubicz 25 A

31-503 Kraków

E-mail: kamil.hebda@inig.pl

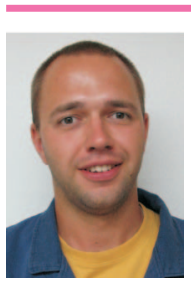

Dr inż. Marek DOHNALIK

Kierownik Zakładu Geofizyki Wiertniczej.

Instytut Nafty i Gazu - Państwowy Instytut Badawczy ul. Lubicz $25 \mathrm{~A}$

31-503 Kraków

E-mail:marek.dohnalik@inig.pl

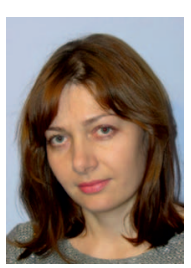

Mgr inż. Justyna HADZIK

Asystent w Instytucie Przemysłu Organicznego

w Warszawie Oddział w Krupskim Młynie.

ul. Zawadzkiego 1

42-693 Krupski Młyn

E-mail: justyna.hadzik@ipo.waw.pl 